\title{
The Effectiveness of Integrated Learning of Immersed Models to Improve Students' Ability on the Environment
}

\author{
Sofia Godeliva Un Lala, Prabowo, Suryanti \\ Universitas Negeri Surabaya \\ Surabaya, Indonesia \\ Sofialala@mhs.unesa.ac.id
}

\begin{abstract}
The main purpose of this study is to describe the effectiveness of integrated learning of immersed models to improve the ability of elementary school students in the environmental field. Education on the environment needs to be organized given the increasingly severe environmental damage symptoms from year to year. This research uses experimental research design that is one group pre-test and post-test design. The results of this study indicate that (1) the implementation of integrated learning of immersed model in Class VI A, class VI $B$ and class VI C shows increasing results in each meeting (2) the students' ability on the environment increases.
\end{abstract}

\section{Keywords-Environmental, Iimmersed Model}

\section{INTRODUCTION}

The era of globalization is marked by the emergence of the development of science and technology that focuses on aspects of information and communication technology, services, and transportation [1].

[2] The development of science and technology has spurred the emergence of industrial society, a society filled with automation, mechanization, and standardization. The negative impact is wastes issued by industries or factories containing hazardous or toxic materials. Various circles of environmentalists have sought an alternative solution to the problems caused by industrial waste as environmental problems because it can disturb the balance of ecosystems, environmental damage, and cause environmental pollution.

Adequate environmental capability is one of the important factors to minimize environmental damage and is an important tool in producing human resources that can implement sustainable development principles. Environmental capability can be provided through environmental education that is undertaken in an effort to increase community understanding and awareness in seeking solutions and prevention of environmental problems. Environmental education is a process of building human populations in a conscious and caring world of the whole environment and all the issues related to it, and people with knowledge, skills, attitudes and behavior, motivation and commitment to work together, individually or collectively, to solve current environmental problems, and prevent new problems to occur [3].

Preliminary observations on four state and private schools in Kupang City indicate a low level of awareness to preserve the environment. The children are likely to throw garbage carelessly and not care of the plants in the classroom, thus, many plants are dry because it is rarely watered. Moreover, the toilet is dirty, and there are no organic and inorganic waste bins and no clean water in the toilet and hand wash. The low awareness to preserve the environment is due to inadequate natural resources along with low awareness of the citizens of the schools on the efforts to save the environment and sustainable development. This happens due to the lack of knowledge of students about the importance of the environment. Students' interest in the environment arises when the video is presented about the current state of environmental damage. The students feel intrigued and touched to see the contents of the video. They feel interested and want to learn more about the environment.

One of the efforts to solve [4] the above problem is by applying a model of learning that is able to facilitate the development of environmental caring as well as to develop students' interest in the environment through learning. By developing the students' interest early on, the feelings will develop and be well embedded in the students. Learning is expected to develop students' love of the environment. Environmental education can be done with an integrated or monolithic curriculum. Material development, learning models and varied learning methods can be done to provide students with an understanding of the environment associated with daily environmental issues. Development can be done with the development of learning models across subjects as well as the excavation and development of materials and environmental issues that exist in the surrounding community[5].

Learning model that is considered to solve the above problem is integrated learning immersed model. This statement is supported by the results of research on 
integrative learning of immersed model to improve students' love of tourism [6] and research conducted [7] using integrated learning of immersed model to develop entrepreneurship spirit. [8] The integrated learning of the immersed model is considered capable of enhancing the love of the environment. Immersed model integrated learning is a learning that uses interdisciplinary approach, where students can combine all data from each field of science and generate thoughts according to their field of interest to be applied in everyday life [9]. The field of student interest in this research is the environment.

The integrated learning tool of the immersed model to improve students' ability on the environment is one of the alternatives that can be done to apply environmental education for elementary students.

\section{METHOD}

This research is a pre-experimental design. The subjects of this study are three classes of grade VI namely class VI A, class VI B and class VI C in SD Inpres Kuanino 2 Kupang. The research design was a One Group Pre-test and Post-test Design.

$$
\begin{array}{lll}
\mathrm{O}_{1} & \mathrm{X} & \mathrm{O}_{2}
\end{array}
$$

(a) $\mathrm{O}_{1}=$ Pre-test, (b) $\mathrm{X}=$ immersed model, (c) $\mathrm{O}_{2}=$ Post-test

The implementation of learning is calculated by summing the number of completed learning activities divided by the total of all aspects multiplied by $100 \%$. Improving the ability of students before and after the learning is measured by looking at the students' n-gain.

\section{RESULTS AND DISCUSSION}

\section{A. The Implementation of Learning}

The implementation of learning is observed by two observers. Learning takes place in three meetings. Overall, the learning execution in percentage is done well. The results of the implementation of learning activities can be seen in Table I.

TABLE I. PERCENTAGE OF THE IMPLEMENTATION OF USING IMMERSED MODEL IN CLASS VI A

\begin{tabular}{ccc}
\hline Meeting & \multicolumn{2}{c}{ Result } \\
1 & Implemented (\%) & Not Implemented (\%) \\
2 & 93 & 7 \\
3 & 95.6 & 4.4 \\
& 97.3 & 2.7 \\
\hline
\end{tabular}

Table I shows that the percentage of the implementation of learning activities using immersed model is increasing at each meeting which means that there is an increase in the quality of learning.
TABLE II. PERCENTAGE OF THE IMPLEMENTATION OF USING IMMERSED MODEL IN CLASS VI B

\begin{tabular}{ccc}
\hline Meeting & Result & \\
1 & Implemented (\%) & Not Implemented (\%) \\
2 & 91 & 8 \\
3 & 94.5 & 5.5 \\
& 97.3 & 2.7 \\
\hline
\end{tabular}

Table II indicates that the percentage of the implementation of learning activities using immersed model is increasing at each meeting which means that there is an increase in the quality of learning.

\begin{tabular}{ccc} 
TABLE III. & \multicolumn{2}{c}{ PERCENTAGE OF THE IMPLEMENTATION OF USING } \\
& IMMERSED MODEL IN CLASS VIC \\
\hline \multirow{2}{*}{ Meeting } & \multicolumn{2}{c}{ Result } \\
1 & Implemented (\%) & Not Implemented (\%) \\
2 & 93.3 & 2.7 \\
3 & 96.7 & 3.4 \\
\hline
\end{tabular}

Table III shows that the percentage of the implementation of learning activities using immersed model is increasing at each meeting which means that there is an increase in the quality of learning.

\section{B. Students' Abilities on the Environment}

Students' ability on the environment was measured twice, before treatment (pre-test) and after treatment (posttest). Differences in test results can be seen in Table IV.

TABLE IV. THE RESULT OF AVERAGE PRE-TEST AND POST-TEST

\begin{tabular}{ccc}
\hline Class & Pre-test & Result \\
VI A & 41 & Post-test \\
VI B & 32 & 75 \\
VI C & 36 & 72 \\
\hline
\end{tabular}

Based on the table, it can be seen that the average pretest result in the VIA class is 41 and the average post-test result in VIA class is 75 . The average of post-test result in VIA class is greater than the average of pre-test result in VIA class. The average pre-test result in the Class VI B is 32 and the average post-test result in Class VI B is 72. The average of post-test result in Class VI B is greater than the average of pre-test result in Class VI B. The average pre-test result in the Class VI C is 36 and the average post-test result in Class VI C is 77. The average of post-test result in Class $\mathrm{VI} \mathrm{C}$ is greater than the average of pre-test result in Class VI C. Overall, the average post-test result is greater than the average pre-test result. 
The students' pre-test and post-test results are used to measure students' understanding of the environment with $\mathrm{n}$ gain. The result of $n$-gain calculation can be seen in table $\mathrm{V}$

TABLE V. RESULT OF N-GAIN

\begin{tabular}{cccc}
\hline Class & N-Gain & $\begin{array}{c}\text { Result } \\
\text { Number of Student } \\
\text { with High N-Gain }\end{array}$ & $\begin{array}{c}\text { Number of Student } \\
\text { with Medium N-Gain }\end{array}$ \\
VI A & 0.7 & 5 & 15 \\
VI B & 0.68 & 6 & 14 \\
VI C & 0.7 & 6 & 14 \\
\hline
\end{tabular}

Based on Table V, it can be seen that in Class VI A the average value of $\mathrm{n}$-gain is 0.7 which is in medium category. The number of students who have high gain is 5 students and the number of students who have a medium gain is 15 students. In class VI $\mathrm{B}$, the average value of $\mathrm{n}$-gain is 0.68 which is in medium category. The number of students who have high gain is 6 students and the number of students who have a medium gain is 14 students. In class VI $\mathrm{C}$, the average value of n-gain is 0.7 which is in medium category. The number of students who have high gain is 6 students and the number of students who have a medium gain is 14 students.

\section{DISCUSSION}

From the results of the study, it can be seen that the percentage of learning implementation increases which indicates the better quality of learning in the class VI A, class VI B, and class VI C. This is because in integrated learning, the immersed model of children is motivated by the insatiable feeling to understand the material according to interest intervention [10].

Enhancement of students' abilities on the environment occurs because students are initially interested in learning about environment. With this interest students will continue to have the will to learn about the environment. The teacher facilitates environment-related materials from four subjects. Students are enthusiastic in following learning activities and are increasingly curious to explore the concept of the environment. With this understanding, students can improve their ability on the environment.

\section{CONCLUSION}

Based on the result of the study, it can be concluded that integrated learning of immersed model is effective to increase students' ability on environment which is seen from the improvement of student learning outcomes.

\section{REFERENCES}

E. Y. Wijaya, D. A. Sudjimat, and A. Nyoto, "Transformasi pendidikan abad 21 sebagai tuntutan pengembangan sumber daya manusia di era global," in Prosiding Seminar Nasional Pendidikan Matematika, 2016, pp. 263-278.
[2] B. Winston, Media, technology and society: A history: From the telegraph to the Internet: Routledge, 2002.

[3] U. UNESCO, "The Tbilisi Declaration," in Intergovernmental Conference on Environmental Education, 1977, pp. 14-26.

[4] S. Cao, "Why large-scale afforestation efforts in China have failed to solve the desertification problem," ed: ACS Publications, 2008.

[5] K. L. H. dan Kehutanan, "Statistik Kementerian Lingkungan Hidup Dan Kehutanan 2014."," ed: Jakarta, 2015.

[6] Handayani, "Pengembangan Pembelajaran Terintegrasi Melalui Model Tenggelam untuk Membangun Pengetahuan Mahasiswa" Unpublish

[7] Afandi, "Develop of Integrated Learning Through Immersed Model to Build Student Knowledge to be Entrepreneur" Unpublish

[8] D. Coyle, P. Hood, and D. Marsh, Content and language integrated learning: Ernst Klett Sprachen, 2010.

[9] R. J. Fogarty and B. M. Pete, How to integrate the curricula: Corwin Press, 2009

[10] R. J. Fogarty and J. Stoehr, Integrating curricula with multiple intelligences: Teams, themes, and threads: Corwin Press, 2008. 